\title{
JURNAL MINERAL, ENERGI DAN LINGKUNGAN

\section{Arah Arus Purba Formasi Bapang Daerah Dayu Dan Sekitarnya Kecamatan Gondangrejo Kabupaten Karanganyar Provinsi Jawa Tengah}

\author{
Fikri Prasetyo $^{1 a}$, Mahap Maha ${ }^{2 b}$ Ediyanto $^{2 c}$ \\ ${ }^{1}$ Alumni Program Studi Teknik Geologi, Fakultas Teknologi Mineral, UPN "Veteran” Yogyakarta \\ $2 b, c$ Dosen Program Studi Teknik Geologi, Fakultas Teknologi Mineral, \\ UPN "Veteran" Yogyakarta J1. SWK 104 (Lingkar Utara), Condongcatur, Yogyakarta 55283 Indonesia \\ a email: fikri_prasetyo@yahoo..id \\ bemail: mahma_semb@yahoo.com \\ cemail: ediyanto_upn@yahoo.co.id
}

Received 14 Okbober2016; Accepted 11 February 2017

Available online 30 April 2017

\begin{abstract}
ABSTRAK
Daerah penelitian secara administrasi terletak di daerah Dayu dan sekitarnya, Kecamatan Gondangrejo, Kabupaten Karanganyar, Provinsi Jawa Tengah. Bagian Utara dari daerah penelitian dibatasi oleh Desa Bukuran, disebelah Timur dibatasi oleh Desa Jembangan, disebelah Barat dibatasi oleh Desa Krandowahono, dan disebelah Selatan dibatasi oleh Desa Rejosari. Stratigrafi daerah penelitian terdiri atas enam satuan litostratigrafi dengan urutan dari tua ke muda adalah Formasi Puren (Pliosen Awal-Akhir), Formasi Cemoro (Plistosen Awal), Formasi Bapang (Plistosen Awal-Tengah), Formasi Pohjajar (Plistosen Tengah), Mud Vulcano (Plistosen Akhir) mengintrusi satuan yang lebih tua sebelumnya, dan satuan Endapan Aluvial (Holosen) yang menumpang tidak selaras di atas batuan yang lebih tua. Struktur geologi yang berkembang pada daerah penelitian dipengaruhi oleh deformasi kedua Zona Kendeng yang berarah utara - selatan. Penelitian arah arus purba di daerah Dayu, menggunakan hasil pengukuran arah sumbu struktur sedimen cross-bedding yang tersebar di Formasi Bapang. Berdasarkan hasil pengukuran arah sumbu cross-bedding di delapan belas lokasi pengukuran, disimpulkan bahwa arah arus purba Formasi Bapang mengarah ke baratlaut dengan tinggian di sebelah tenggara. Arah arus purba Formasi Bapang berpola Unimodal (Tucker, 2003) yang mencirikan lingkungan pengendapan Fluvial, dengan material vulkanik yang diperkirakan bersumber dari sebelah tenggara lokasi penelitian.
\end{abstract}

Kata Kunci : Arus Purba, Unimodal, CrossBedding

\section{ABSTRACT}

Administrative research area located in Dayu and the surrounding area, District Gondangrejo, Karanganyar, Central Java Province. The northern part of the study area bounded by Bukuran Village, on the east bounded by Jembangan village, on the west bounded by Village Krandowahono, and on the south bounded by Village Rejosari. Stratigraphic research area consists of six units of litostratigraphy with the order from the old to the young is Puren Formation (Early-late Pliocene), Cemoro Formation (Early Plistosen), Bapang Formation (Early-Middle Plistosen), Pohjajar Formation (Plistosen Central), Mud Vulcano (Plistosen end) which have intrusion the older units, and the units of Alluvial Deposits (Holocene) which have unconformity on top of the older rocks. Geological structures developed in the study area is influenced by the deformation of the second Kendeng's zone that has trending north - south. Research of the paleocurrent direction in the area of Dayu, using the results of the measurement of the direction of the axis of the sedimentary structure of crossbedding scattered on Bapang Formation. Based on the results of the measurement of the direction of the axis of cross-bedding in eighteen location measurements, it was concluded that the paleocurrent direction Bapang Formation has trending to the Northwest with highest area in the Southeast. The paleocurrent direction of Bapang Formation has Unimodal patterned (Tucker, 2003) that characterizes the environment of Fluvial deposition, with the estimated volcanic materials sourced from Southeast research location.

Keywords: Paleocurrent, Unimodal, CrossBedding 


\section{PENDAHULUAN}

Daerah Dayu termasuk dalam Kawasan Situs Purba Sangiran yang terkenal menyumbangkan data penting bagi pemahaman sejarah evolusi fisik manusia, maupun lingkungan keadaan alam purba. Stratigrafi di Sangiran menunjukkan proses perkembangan evolusi dari lingkungan laut yang berangsur-angsur berubah menjadi lingkungan daratan, seperti tercermin dari fosil-fosil yang ditemukan pada masing-masing formasi.

Daerah ini menyimpan banyak misteri yang harus diungkap, konon dahulu Sangiran sempat menjadi lingkungan sungai. Hal tersebut dapat terekam pada Formasi Bapang, yang terdiri dari litologi, Batupasir, tuff, dan Konglomerat dengan struktur sedimen crossbedding.

Cross-bedding adalah struktur sedimen yang membatasi unit sedimentasi yang terdiri dari lapisan- lapisan internal (foreset bedding), yang condong kearah bidang pengendapan. Struktur cross-bedding memiliki arah sumbu utama yang dalam kondisi normal (sebelum terdeformasi), dapat menunjukan arah pengendapan material sedimen. Struktur sedimen ini adalah struktur yang terbaik untuk digunakan dalam pengukuran arah arus purba.

Kondisi fisik Formasi Bapang di daerah Dayu telah dipengaruhi oleh proses tektonik deformasi kedua zona Kendeng pada zaman Kuarter, yang berlangsung secara lambat dan mengakibatkan terbentuknya struktur kubah di Sangiran. Deformasi ini menyebabkan perubahan posisi kedudukan lapisan batuan pada Formasi bapang, serta merubah arah sumbu utama struktur sedimen cross-bedding dari posisi sebenarnya. Sehingga perlu dilakukan pengukuran secara khusus untuk mengetahui arah sumbu utama struktur cross-bedding serta analisis pengaruh deformasi terhadap perubahan arah sumbu tersebut, guna mengetahui arah arus purba yang membawa material sedimen penyusun Formasi Bapang di masa lampau.

Penelitian ini dilakukan secara terperinci di daerah Dayu dan sekitarnya, Kecamatan Gondangrejo, Kabupaten Karanganyar, Provinsi Jawa Tengah. Waktu penelitian berlangsung selama satu bulan di lapangan, terhitung dari 10 November 2014 sampai 10 Desember 2014. Kemudian dilanjutkan dengan kegiatan pengolahan data, analisis data, dan pembuatan laporan penelitian, sebagai sistematika selama kegiatan penelitian berlangsung. Kegiatan tahap lanjut ini memakan waktu 4 bulan.

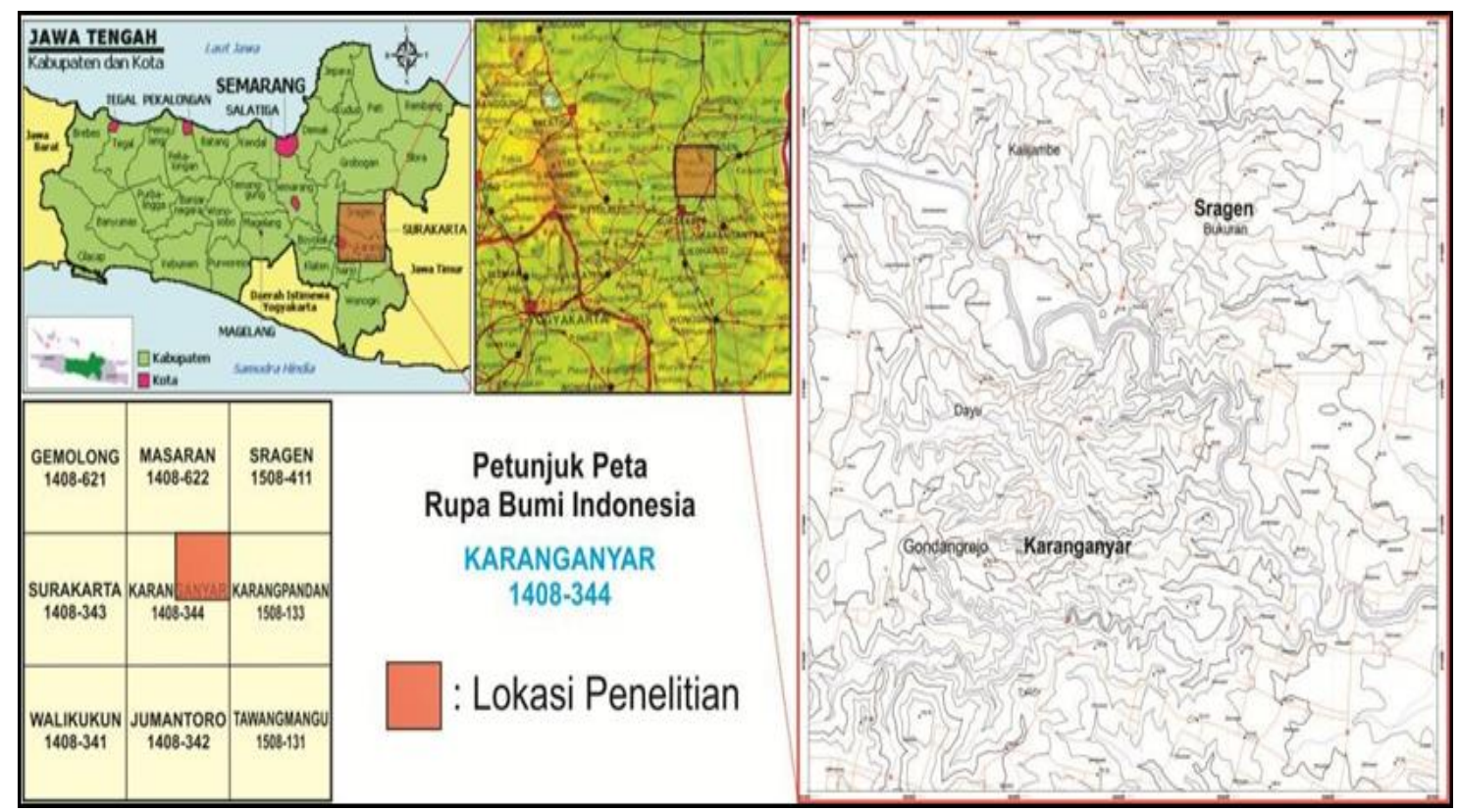

Gambar 1. Lokasi Penelitian 


\section{METODE PENELITIAN}

Metode yang digunakan untuk melakukan penelitian ini dapat dilihat melalui tahapan-tahapan dalam sistematika kerja yang dikemukakan dalam tahapan sebagai berikut :

\section{Studi Pustaka}

Studi pustaka mengenai geologi daerah telitian, yang terdiri dari geologi regional, stratigrafi regional, dan struktur geologi regional guna memproyeksikan kondisi regional ke lokal daerah penelitian. Tujuannya adalah untuk mengetahui kejadian geologi yang berkembang di derah telitian.

\section{Tahap Pra-Mapping}

Tahap pra-mapping berupa kegiatan observasi dan survey lapangan guna menentukan lokasi dan luas daerah penelitian yang sesuai dengan topik judul yang akan diteliti. Setelah lokasi penelitian didapatkan, pada tahap ini juga dilakukan perijinan dan penyiapan peta dasar guna memperlancar proses pelaksanaan tahapan kerja berikutnya.

\section{Tahap Pemetaan (Mapping)}

Tahap pemetaan berupa kegiatan pengumpulan data lapangan, yaitu dengan melakukan tahapan kerja berupa: penentuan koordinat serta perekaman lokasi pengamatan, pengamatan dan diskripsi singkapan batuan, pembuatan sketsa singkapan batuan, pengukuran kedudukan lapisan batuan, pengambilan foto singkapan dan sampel batuan, pengamatan struktur geologi yang berkembang, dan pengukuran arah arus purba.

Pengambilan data arus purba di lapangan dengan cara pengukuran arah struktur-struktur sedimen tertentu. Dari hasil pengukuran tersebut, dapat diketahui arah arus purba yang mencerminkan kondisi regional paleoslope dari suatu daerah. Arus purba memiliki peranan penting dalam interpretasi fasies.

Pada penelitian ini, data yang digunakan adalah data struktur sedimen cross-bedding untuk menetahui arah arus purba. Pengukuran arah arus purba menggunakan struktur sedimen crossbedding, dapat dilakukan dengan mengukur dip direction pada lapisan internal di setiap foreset bedding.

Pengukuran pada struktur trough crossbedding (silangsiur berbentuk mangkok), dilakukan dengan mengukur kedudukan sayap-sayap pada struktur sedimen tersebut untuk mendapatkan arah penujaman dari sumbu sayapsayapnya. Pengukuran dapat dilakukan seara langsung dilapangan dengan mengukur arah penujaman dari sumbu utama sayap struktur tersebut di lapangan.

\section{Analisis Data}

Pada tahapan ini meliputi berbagai macam kegiatan yang dilaksanakan di studio, diantaranya: analisa data geologi Formasi Bapang guna penentuan satuan batuan Formasi Bapang, penentuan lingkungan pengendapan berdasarkan data penampang stratigrafi terukur, dan mengetahui pengaruh struktur geologi.

Analisa hasil pengukuran arah arus purba Formasi Bapang, dengan menghimpun data pengukuran masingmasing lokasi pengamatan dalam diagram roset. Selanjutnya data arah umum suatu lokasi di analisa menggunakan stereonet, guna mengetahui arah arus purba yang sebenarnya. Hasil tersebut digunakan untuk data pendukung dalam penentuan lingkungan pengendapan berdasarkan pola arah arus purba dan dikorelasikan dengan hasil analisa lingkungan pengendapan dari measuring section.

\section{GEOLOGI REGIONAL}

\section{Fisiografi}

Fisiografi daerah penelitian termasuk kedalam Zona Kendeng yang merupakan antiklinorium dengan arah umum barat-timur. Bagian utaranya dibatasi oleh Depresi Randublatung, sedangkan bagian selatan dibatasi oleh jajaran gunung api (Zona Solo). Zona Kendeng merupakan kelanjutan dari Zona Pegunungan Serayu Utara yang berkembang di Jawa Tengah. Mandala Kendeng terbentang mulai dari Salatiga ke timur sampai ke Mojokerto dan menunjam di bawah alluvial Sungai Brantas, kelanjutan pegunungan ini masih dapat diikuti hingga di bawah Selat Madura.

Menurut Bemmelen (1949), Zona Kendeng dibagi menjadi 3 bagian, yaitu bagian barat yang terletak di antara Gunung Ungaran dan Solo (utara Ngawi), bagian tengah yang membentang hingga Jombang dan bagian timur mulai dari timur Jombang hingga Delta Sungai Brantas dan menerus ke Teluk Madura. Daerah penelitian termasuk dalam Zona Kendeng bagian barat. 


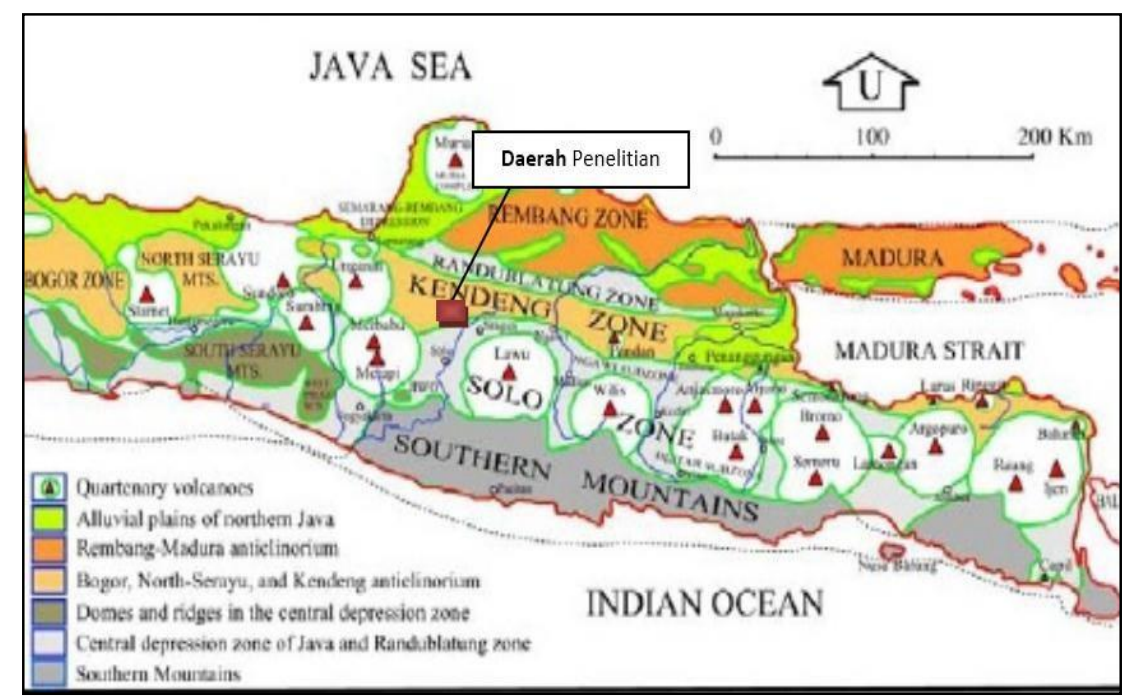

Gambar 2. Fisiografi Pulau Jawa (Bemmelen,1949)

\section{Stratigrafi}

Daerah Dayu termasuk kedalam Situs Sangiran, yang merupakan warisan dunia yang sangat menarik untuk dilakukan penelitian. Telah banyak peneliti yang melakukan penelitian terlebih dahulu, berikut ini adalah penelitinya. Antara lain yaitu:

- Van Es pada tahun 1931 tidak ada pemberian Formasi pada peneliti tersebut, namun di jumpai Konglomerat atas dengan boulder breksi dan tuf sedangkan konglomerat bawah di jumpai konglomerat dan tuf, breksi vulkanik, batulempung, lempung hitam, batugamping dengan banyak mengandung fosil Balanus, Corbicula, Turritella.

- Pada tahun 1936, Duyfjes melakukan penelitian, namun penelitian dilakukan di sebelah timur Sangiran dengan jarak yang sangat jauh antara 100-180 km. Duyfjes membagi empat Lapisan, yaitu Lapisan Kalibeng, Lapisan Pucangan, Lapisan Kabuh, dan Lapisan Notopuro. Kalibeng atas terdiri dari batugamping, batugamping Globigerina, batupasir dengan sisipan Glokonite sedikit mengandung foraminifera. Kalibeng bawah terdiri dari Monotous Globigerina, dan mengandung banyak fosil Lepidocyclina, Lapisan ini berumur miosen. Kemudian Lapisan Cemoro, bagian atas Lapisan ini terdiri litologi batupasir tufan, batupasir tufan dengan sisipan lempung dan setempat di jumpai moluska laut, konglomerat, banyak juga di jumpai breksi dengan fragmen andesit, lapisan paling atas terdiri dari batupasir tufan dengan mengandung moluska marin dan Echinoids, batulempung hijau. Kemudian Lapisan Kabuh terdiri dari batupasir tufan silang siur dengan sisipan konglomerat dan tuffan halus. Tulang-tulang fosil Vertebrata ke dalam fauna Trinil di jumpai di dalam batupasir (Plistosen Tengah). Terakhir adalah Lapisan Notopuro terdiri dari perselingan batupasir tufan, breksi dan konglomerat. Umunya endapan pada formasi ini merupakan endapan vulkanik klastik.

- Van Koenigswald pada tahun 1940, melakukan penelitian di Sangiran dan sekitarnya. Pembagian nama Lapisan oleh Van Koenigswald di Sangiran mengikuti Duyfjes, yaitu Lapisan Kalibeng, Lapisan Pucangan, Lapisan Kabuh dan Lapisan Notopuro. Lapisan Kalibeng atas terdiri dari batugamping yang banyak mengandung Balanus, batupasir marin, batulempung marin dan lapisan Corbicula. Kemudian Lapisan Pucangan terdiri dari lempung hitam (air tawar), lempung kuning (laut), breksi vulkanik lower. Setelah itu Lapisan Kabuh yang terdiri Grenzbank, konglomerat dan tuf lower. Istilah Grenzbank dikemukakan oleh Van Koenigswald pertama kali, yaitu sebagai batas antara Lapisan Pucangan dan Lapisan Kabuh. Dan terakhir Formasi Notopuro terdiri dari breksi vulkanik upper, konglomerat upper dan tuf. Van Koenigswald menyatakan bahwa umur Lapisan Kalibeng, Pucangan, Kabuh dan Notopuro berturut-turut adalah Lapisan Kalibeng berumur Pliosen dan Lapisan Pucangan, Kabuh, Notopuro berumur Plistosen Awal.

- Kemudian Sartono pada tahun 1961,1970,1975, 1978, mengungkapkan bahawa Sangiran terdiri dari empat lapisan, sama halnya dengan peneliti sebelumnya. Kalibeng atas terdiri dari lempung marin dan batupasir marin yang banyak mengandung Turritella, batugamping mengandung belanus dan lapisan Corbicula, Lapisan Kalibeng berumur Pliosen Akhir. Kemudian Lapisan Pucangan litologinya meliputi lempung hitam dan lempung kuning serta breksi vulkanik lower yang berumur Plistosen Awal. Setelah itu Lapisan Kabuh yang litologinya berupa konglomerat lower, batupasir dan tuf yang berumur Plistosen Tengah. Dan terakhir Lapisan Notopuro terdiri dari konglomerat upper dan endapan-endapan vulkanik yang berumur Plistosen Tengah. Pada tahun 1978, Sartono mengubah istilah Lapisan menjadi Formasi. 
- Indonesia-Japan Research Coporation Programme CTA 41 (IJRCP CTA 41) pada tahun 1979, memberi litologi dari Formasi Kalibeng di Sangiran yaitu lempung dengan warna abu-abu kebiruan dengan sispan tuf yang berukuran kasar mengandung mineral-mineral berat, ditutupi oleh batupasir yang mengandung Operculina, batugamping balanus dan lapisan Corbicula. Kemudian Formasi Pucangan terdiri dari breksi vulkanik di bagian bawah dan batulempung hitam bagian atas, molluska dan koral. Setelah itu pemerian Formasi Kabuh terdiri dari kerikil, batupasir, lanau, lacustrine dan lempung fluvial dengan lapisan tuf. Terakhir Formasi Notopuro yang terdiri dari kerikil, batupasir, lanau, lempung, breksi vulkanik, pumice tuf dan tuf.Pringgoprawiro pada tahun 1983, dalam disertasinya mengatakan pada Formasi Kalibeng berupa tufan pasiran, batupasir gampingan. Terdapat fosil Gr. Tumida, Gr. multicamorata, Gr. miocenica, P. mraecursor. Kemudian Formasi Pucangan terdiri batupasir tufan dengan sisipan breksi, tufan napalan mengandung cangkang moluska melanoides.sp (air tawar) dan Palecypoda, Gastropoda (marine). Formasi Kabuh terdiri dari Lanau, batupasir, batupasir dengan sisipan lempung, konglomerat. Formasi Notopuro berupa tufan pasiran, breksi dan batupasir. Penelitian ini dilakukan di Jombang hingga Ngawi.

- Watanabe dan Darwin Kadar pada tahun 1985 mengusulkan nama-nama baru Formasi yang terdapat di Sangiran. Formasi Kalibeng diganti dengan Formasi Puren, Formasi Pucangan diganti menjadi Formasi Sangiran, Formasi Kabuh menjadi Formasi Bapang, Formasi Notopuro menjadi Formasi Pohjajar.

- Tahun 1987, Danisworo mendukung pergantian nama Formasi oleh Watanabe dan Darwin Kadar di daerah Sangiran dan sekitarnya. Hal ini dikarenakan nama formasi sebelumnya lokasi tipenya sangat jauh dari daerah Sangiran, yang jaraknya kurang lebih 100-150 kilometer. Namun Danisworo mengganti nama Formasi Sangiran menjadi Formasi cemoro.

Situs Sangiran terkenal menyumbangkan data penting bagi pemahaman sejarah evolusi fisik manusia, maupun lingkungan keadaan alam purba. Stratigrafi di Sangiran menunjukkan proses perkembangan evolusi dari lingkungan laut yang berangsur-angsur berubah menjadi lingkungan daratan, seperti tercermin dari fosil-fosil yang ditemukan pada masing-masing formasi. Penamaan Formasi batuan dalam penelitian ini, penulis mengacu pada peneliti terdahulu yang melakukan kegiatan pemetaan geologi di daerah Sangiran yaitu Danisworo (1987).

\section{Struktur Geologi}

Deformasi pertama pada Zona Kendeng terjadi pada akhir Pliosen (Plio - Plistosen), deformasi merupakan manifestasi dari zona konvergen pada konsep tektonik lempeng yang diakibatkan oleh gaya kompresi berarah relatif utara - selatan dengan tipe formasi berupa ductile yang pada fase terakhirnya berubah menjadi deformasi brittle berupa pergeseran blok - blok dasar cekungan Zona Kendeng. Intensitas gaya kompresi semakin besar ke arah bagian barat Zona Kendeng yang menyebabkan banyak dijumpai lipatan dan sesar naik dimana banyak zona sesar naik juga merupakan kontak antara formasi atau anggota formasi.

Deformasi Plio - Plistosen dapat dibagi menjadi tiga fase, yaitu; fase pertama berupa perlipatan yang mengakibatkan terbentuknya Geantiklin Kendeng yang memiliki arah umum barat-timur dan menunjam di bagian Kendeng Timur, fase kedua berupa pensesaran yang dapat dibagi menjadi dua, yaitu pensesaran akibat perlipatan dan pensesaran akibat telah berubahnya deformasi ductile menjadi deformasi brittle karena batuan telah melampaui batas kedalaman plastisnya. Kedua sesar tersebut secara umum merupakan sesar naik bahkan ada yang merupakan sesar sungkup. Fase ketiga berupa pergeseran blok-blok dasar cekungan Zona Kendeng yang mengakibatkan terjadinya sesar- sesar geser berarah relatif utara-selatan.

Deformasi kedua terjadi selama kuarter yang berlangsung secara lambat dan mengakibatkan terbentuknya struktur kubah di Sangiran. Deformasi ini masih berlangsung hingga saat ini dengan intensitas yang relatif kecil dengan bukti berupa terbentuknya sedimen termuda di Zona Kendeng yaitu Endapan Undak. 


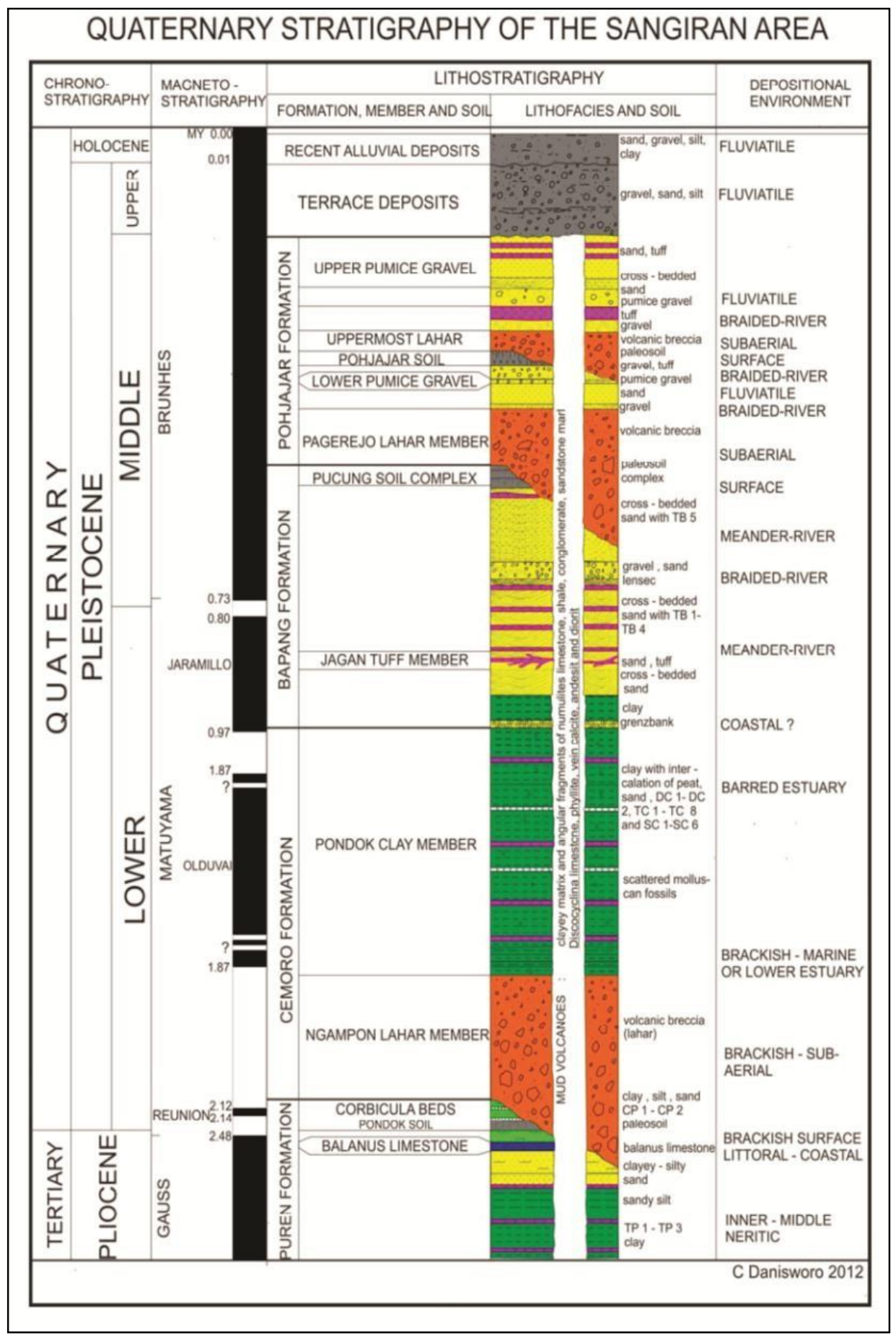

Gambar 3.Stratigrafi daerah Sangiran dan sekitarnya (Danisworo, 1987) 


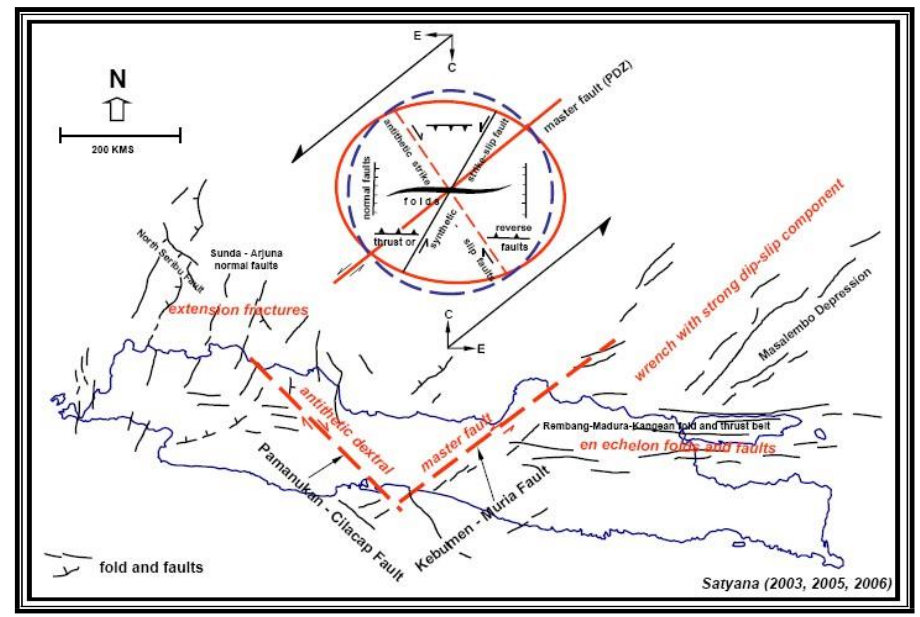

Gambar 4. Struktur Geologi Jawa berdasarkan strain ellipsoid kinematics models (Satyana dan Arman, 2004)

\section{Formasi Bapang}

Formasi Bapang Terdiri dari batupasir tufan dengan sisipan batupasir, tuf pasiran, konglomerat, dan grenzbank pada bagian bawah. Batupasir tufan berwarna coklat cerah, berukuran pasir halus - kasar, terpilah sedang - buruk, membundar - menyudut tanggung, kemas terbuka, tersusun oleh plagioklas, piroksen, lithic tuf, dan mineral mafik, semen silika, struktur sedimen perlapisan, graded bedding, trough cross-bedding dan plannar cross-bedding.

Batupasir berwarna abu-abu kecoklatan, berukuran pasir halus-sedang, terpilah sedang, membundar-menyudut, kemas terbuka-tertutup, tersusun oleh kuarsa, piroksen, plagioklas, dan mineral mafik, semen silika, struktur sedimen perlapisan, dan cross-bedding. Tuf pasiran berwarna putih cerah, berukuran pasir sangat halus-halus, terpilah sedang, menyudut, tersusun oleh piroksen dan plagioklas dalam masa dasar tuf, struktur sedimen perlapisan, masif.
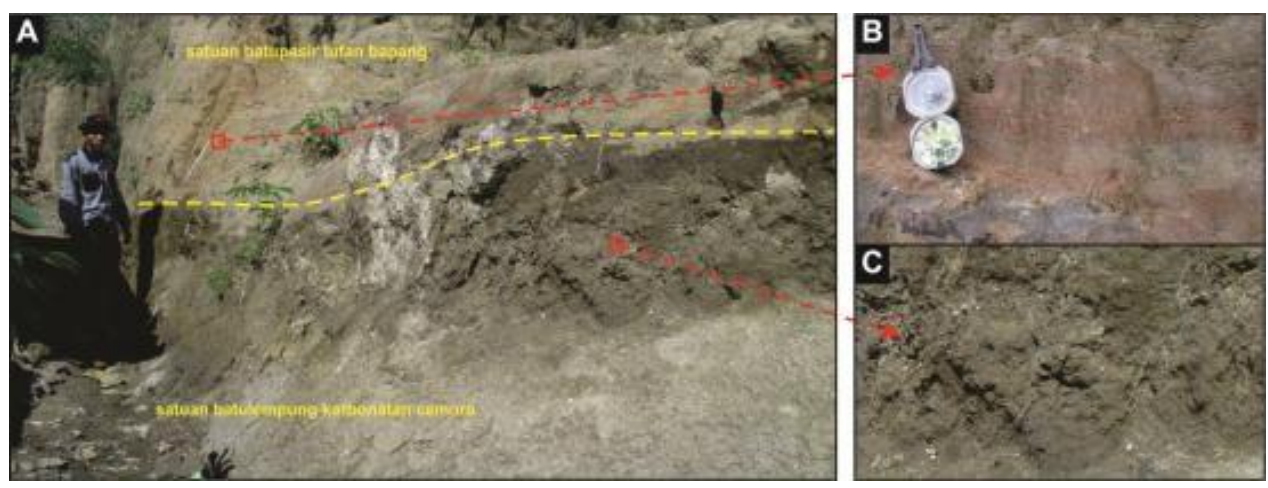

Foto 1. Kontak satuan batulempung karbonatan Cemoro dan batupasir tufan Bapang, A. Kenampakan perubahan litologi dan struktur sedimen secara berangsur; B. Batupasir tufan Bapang dengan struktur sedimen cross-bedding; C. Singkapan batupasir karbonatan dengan kandungan pecahan cangkang moluska.

Konglomerat dengan warna abu-abu gelap, berukuran krikil-krakal, terpilah buruk, kemas terbuka, membundar-membundar tanggung, tersusun oleh andesit, dan batupasir tufan sebagai fragmen, batupasir halus, dan mineral mafik sebagai matriks, masif. Grenzbank dengan warna abu-abu kecoklatan, berukuran krikil-krakal, terpilah buruk, kemas terbuka, membundar-menyudut, tersusun oleh andesit, tuf pasiran, lanau yang tertanam sebagai fragmen, dan piroksen, hornblende, kuarsa, dan mineral mafik sebagai matriks, semen silika. Sangat keras dengan struktur sedimen masif. Menurut Danisworo (1987), umur dari Formasi ini adalah Plistosen Awal-Plistosen Tengah.

Formasi ini diendapkan secara selaras diatas Formasi Cemoro. Kenampakan dilapangan berupa adanya kontak tegas, serta perubahan litologi dan struktur sedimen yang berangsur. Diatasnya diendapkan secara selaras Formasi Pohjajar. 

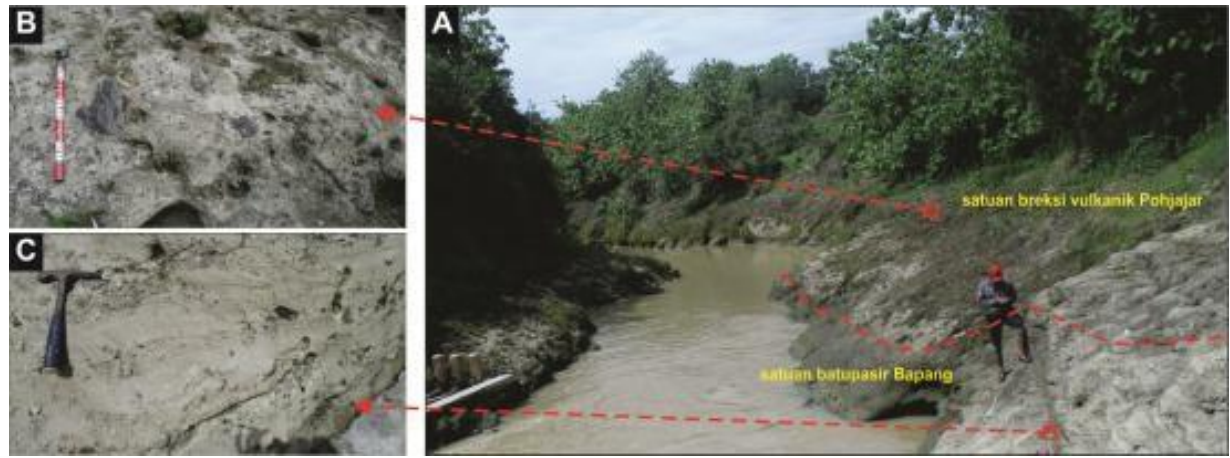

Foto 2. Kontak satuan batupasir tufan Bapang dan breksi vulkanik Pohjajar, A. Kenampakan perubahan litologi dan struktur sedimen secara berangsur; B. Kenampakan breksi vulkanik dengan struktur masif; C. Singkapan batupasir tufan dengan strukturtrough cross-bedding.

Lingkungan pengendapan Formasi Bapang di tentukan berdasarkan dua aspek, yakni aspek fisik dan aspek kimiawi. Aspek fisik yang dijumpai meliputi Litolologi yang menyusun berupa batupasir dengan ukuran butir pasir halus-pasir sangat kasar, dan konglomerat. Struktur sedimen yang berkembang trough cross-bedding, plannar cross- bedding, dan graded bedding. Sedangkan aspek kimiawinya, dilihat dari komposisi semen yang terkandung pada litologi penyusun tidak memiliki kandungan $\mathrm{CaCO} 3$, menandakan tidak terdapat pengaruh daerah laut pada saat pengendapan. Warna kemerahan pada batuan menunjukan adanya proses oksidasi yang terjadi, disebabkan oleh adanya kontak udara pada saat batuan terendapkan dan tidak dijumpai adanya fosil foraminifera plankton maupun bentos. Dari dua aspek tersebut serta mengacu kepada model pendekatan lingkungan pengendapan Nichols (2009), dapat disimpulkan bahwa formasi ini terendapkan pada lingkungan sungai yang berkelok-kelok (Meandering River) pada bagian channel-fill sands.

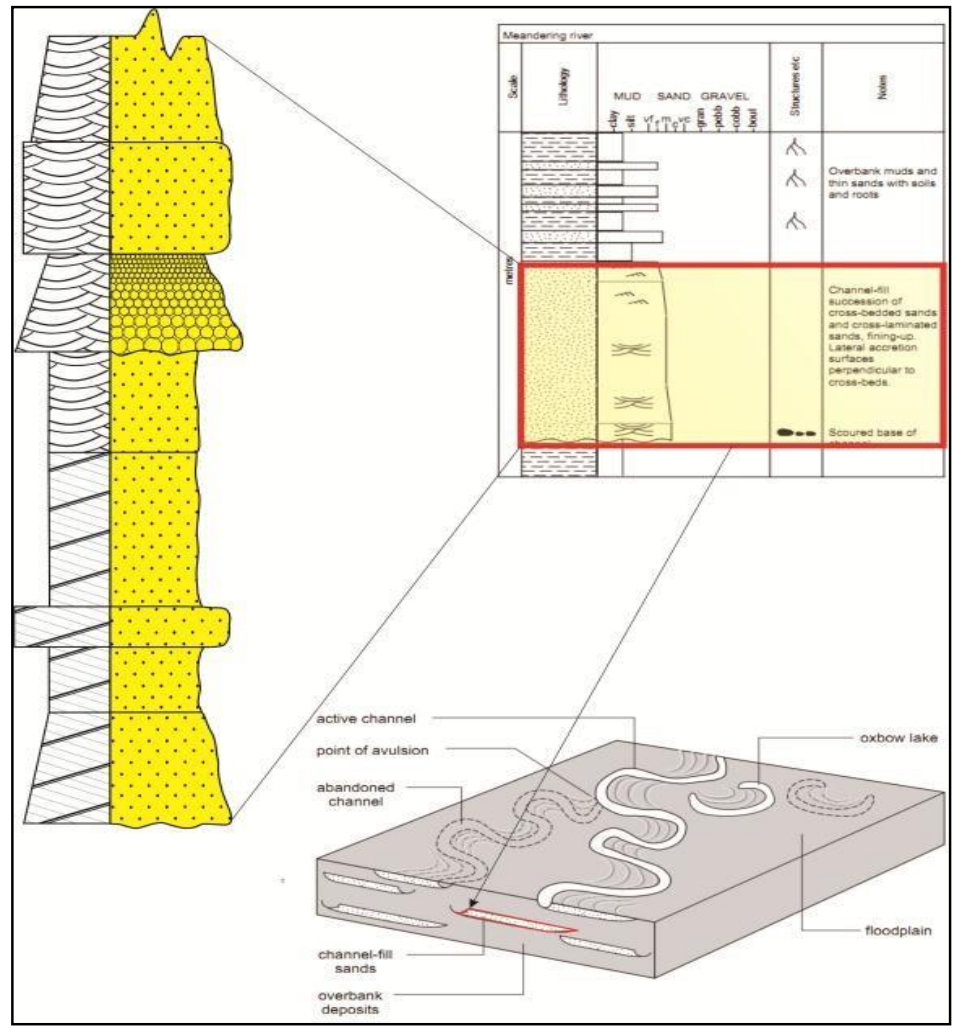

Gambar 5. Hasil analisa penampang stratigrafi terukur, model pendekatan interpretasi lingkungan pengendapan (Nichols, 2009) 


\section{Arah Arus Purba Formasi Bapang}

Formasi Bapang yang diendapkan pada fasies Meandering River pada bagian Chanel fill. Pada lingkungan ini, struktur cross-bedding berkembang baik, sehingga memudahkan untuk melakukan pengukuran arah arus purba. Hasil pengamatan dilapangan menunjukan bahwa struktur sedimen cross-bedding yang berkembang dominan pada daerah telitian adalah struktur trough cross-bedding. Pengukuran di lapangan dengan menggunakan kompas geologi, dan dilakukan pada arah penujaman dari struktur trough cross-bedding. Pada penelitian ini dilakukan pengukuran arah arus purba sebanyak 276 buah pengukuran pada 18 titik pengamatan yang diamati. Data yang didapat dari pengukuran lapangan kemudian dikoreksi dengan menggunakan stereonet. Analisa stereografis digunakan, karena daerah telitian telah dipengaruhi oleh proses

\section{deformasi kedua Zona Kendeng.}

Proses deformasi ini menyebabkan Formasi Bapang mengalami pengangkatan dan perlipatan yang menghasilan struktur geologi berupa kubah. Sehingga kedudukan lapisan batuan Formasi Bapang berubah mengikuti pola kubah yang terbentuk. Pada penelitian ini, analisa Stereografis digunakan untuk menghorizontalkan kembali lapisan batuan dan untuk mengetahui arah asli dari arus purba yang terekam pada sumbu struktur sedimen trough cross- bedding.

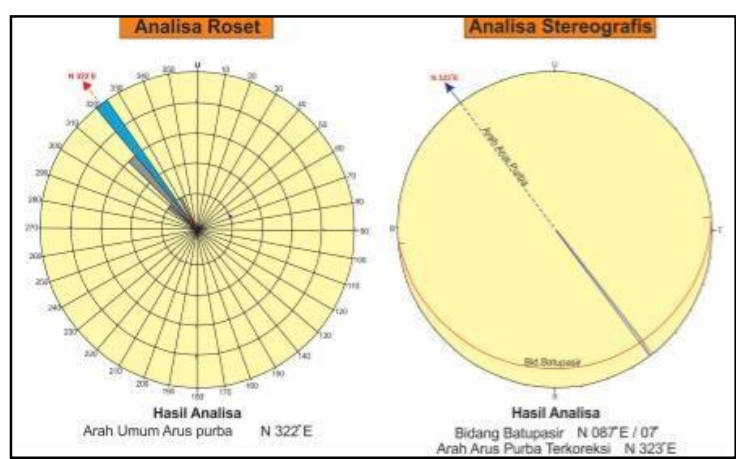

Gambar 6. Contoh analisa arus purba hasil pengukuran dilapangan menggunakan diagram rosette, dan koreksi dengan analisa stereografis

Gambar diatas merupakan contoh analisa hasil pengukuran arus purba dilapangan. Pada contoh ini dijelaskan bahwa dari data pengukuran dilapangan didapatkan arah umum dari diagram rosette bernilai $\mathrm{N} 322^{0} \mathrm{E}$. Arah arus purba tersebut di koreksi menggunakan analisa stereografis, dengan cara "menghorizontalkan" kedudukan lapisan batuan tempat struktur tersebut diukur. Analisa ini dilakukan untuk mendapatkan arah arus saat batuan diendapkan, sebelum terdeformasi. Setelah dikoreksi, didapatkan arah arus purba saat pengendapan dengan arah $\mathrm{N} 323^{0} \mathrm{E}$. Tahapan analisis ini dilakukan di setiap lokasi pengukuran arus purba, sehingga dapat disusun dalam satu analisis arus purba kompilasi guna mengetahui pola arah arus purba daerah telitian.

Tabel 1. Data hasil pengukuran arah arus purba

\begin{tabular}{|c|c|c|c|}
\hline LP & Arah Umun Arus Purba & Kedudukan Batuan & Arah Arus Purba Terkoreksi \\
\hline 4 & $\mathrm{~N} 338^{\circ} \mathrm{E}$ & $\mathrm{N} 338^{\circ} \mathrm{E} / 12^{\circ}$ & $\mathrm{N} 337^{\circ} \mathrm{E}$ \\
\hline 45 & $\mathrm{~N} 349^{\circ} \mathrm{E}$ & $\mathrm{N} 008^{\circ} \mathrm{E} / 07^{\circ}$ & $\mathrm{N} 349^{\circ} \mathrm{E}$ \\
\hline 57 & $\mathrm{~N} 306^{\circ} \bar{E}$ & N032 E/ $09^{\circ}$ & $\mathrm{N} 306^{\circ} \bar{E}$ \\
\hline 60 & $\mathrm{~N} 321^{1} \mathrm{E}$ & $\mathrm{N} 351^{\circ} \mathrm{E} / 07^{\prime \prime}$ & $\mathrm{N} 321^{\circ} \mathrm{E}$ \\
\hline 61 & $\mathrm{~N} 348^{\circ} \mathrm{E}$ & N037 E $08^{\circ}$ & N347 E \\
\hline 62 & $\mathrm{~N} 337^{\circ} \mathrm{E}$ & $\mathrm{N} 332^{\circ} \mathrm{E} / 07^{\circ}$ & $\mathrm{N} 337^{\mathrm{E}} \mathrm{E}$ \\
\hline 64 & $\mathrm{~N} 344^{\circ} \overline{\mathrm{E}}$ & $\mathrm{N} 357 \mathrm{E} / 07$ & $\mathrm{~N} 344^{\circ} \overline{\mathrm{E}}$ \\
\hline 66 & $\mathrm{~N} 262^{\circ} \mathrm{E}$ & N072 E $/ 09^{\circ}$ & $\mathrm{N} 263^{\circ} \mathrm{E}$ \\
\hline 98 & $\mathrm{~N} 012 \mathrm{E}$ & N037 E $/ 05^{\circ}$ & $\mathrm{N} 012 \mathrm{E}$ \\
\hline 104 & $\mathrm{~N} 333^{\circ} \mathrm{E}$ & $\mathrm{N} 033^{\circ} \mathrm{E} / 09^{\circ}$ & $\mathrm{N} 332^{\circ} \mathrm{E}$ \\
\hline 117 & $\mathrm{~N} 326^{\circ} \mathrm{E}$ & $\mathrm{N} 133^{\circ} \mathrm{E} / 06^{\circ}$ & $\mathrm{N} 327^{\circ} \mathrm{E}$ \\
\hline 133 & $\mathrm{~N} 355^{\circ} \mathrm{E}$ & N091 E/ $09^{\prime \prime}$ & $\mathrm{N} 355^{\circ} \mathrm{E}$ \\
\hline 137 & $\mathrm{~N} 316 \mathrm{E}$ & N098 E/ $15^{\circ}$ & N317E \\
\hline 163 & $\mathrm{~N} 284^{\circ} \mathrm{E}$ & N051 E/ $05^{\circ}$ & $\mathrm{N} 284^{\circ} \mathrm{E}$ \\
\hline 185 & $\mathrm{~N} 322^{\circ} \mathrm{E}$ & $\mathrm{N} 087^{\circ} \mathrm{E} / 07^{\circ}$ & $\mathrm{N} 323^{\circ} \mathrm{E}$ \\
\hline 187 & $\mathrm{~N} 379^{\circ} \mathrm{E}$ & $\mathrm{N} 106^{\circ} \mathrm{E} / 05^{\circ}$ & $\mathrm{N} 279^{\circ} \mathrm{E}$ \\
\hline 193 & $\mathrm{~N} 316^{\circ} \mathrm{E}$ & N077 E/ OT & $\mathrm{N} 317 \mathrm{E}$ \\
\hline 195 & $\mathrm{~N} 300^{\circ} \mathrm{E}$ & N049 E $/ 09^{\circ}$ & $\mathrm{N} 301^{\circ} \mathrm{E}$ \\
\hline
\end{tabular}

$\sim$ Fiki Prasetyo, Mahap Maha, Ediyanto 
Hasil pengukuran dan analisa arah arus purba dari 18 lokasi pengamatan, didapatkan pola penyebaran arah arus purba yang cenderung menuju ke 1 arah, yakni arah Baratlaut. Pola ini disebut pola unimodal (Tucker, 2003), yang dijadikan acuan untuk menentukan lingkungan pengendapan Formasi Bapang berdasarkan arah arus purba.
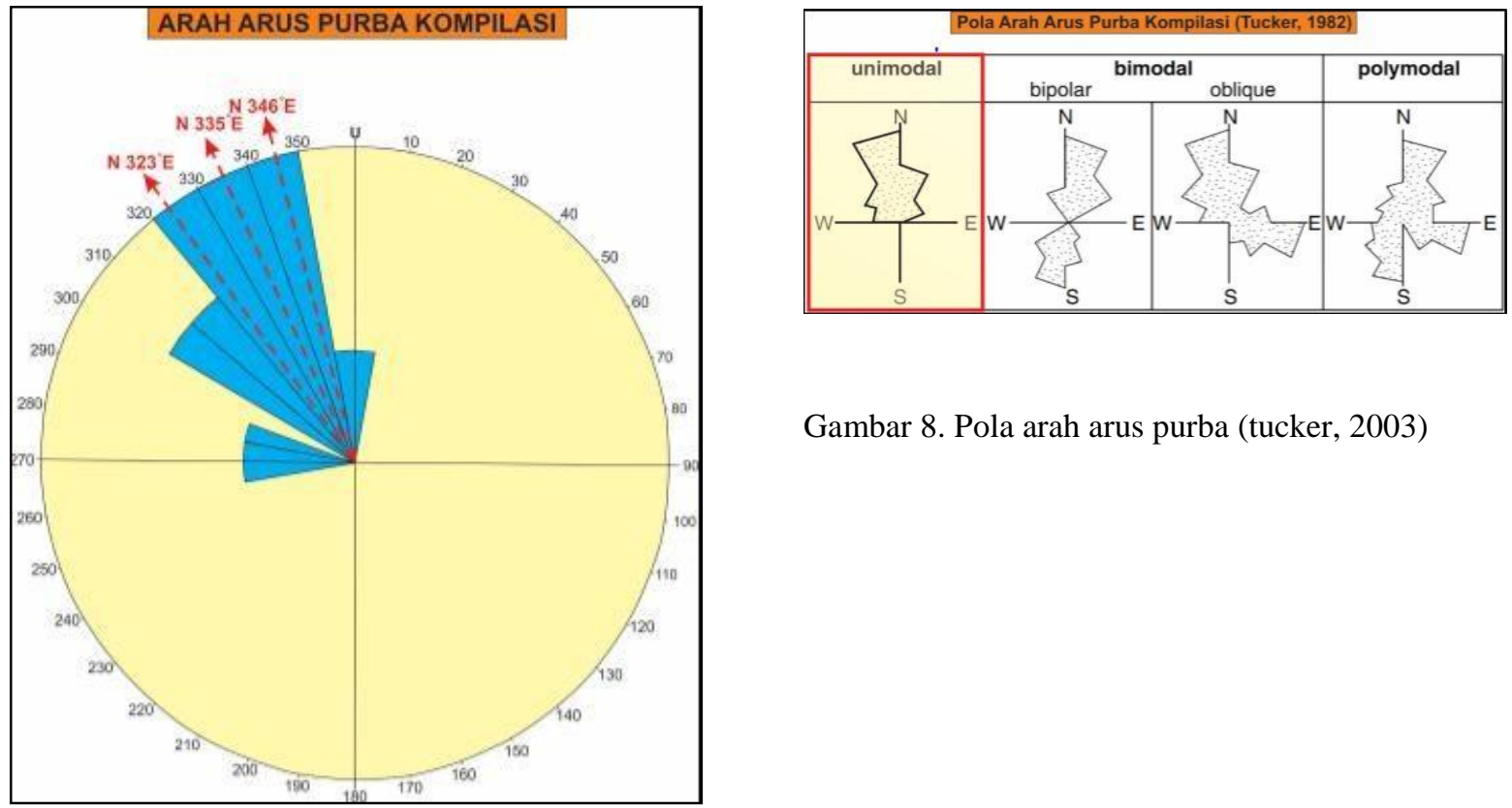

Gambar 8. Pola arah arus purba (tucker, 2003)

Gambar 7. Diagram rosette arah arus purba kompilasi

Pola arus purba yang mengarah ke baratlaut menunjukan adanya kelerengan purba (paleoslope) dengan daerah tinggian di sebelah Tenggara. Berdasarkan analisa diagram roset kompilasi dan peta sebaran arah arus purba, dapat dilihat Pola unimodal dengan kenampakan arah arus yang menyebar (dispersion) yang kemungkinan disebabkan oleh kelokan sungai. Kenampakan demikian didukung oleh hasil analisa penampang stratigrafi terukur (measuring section) pada Formasi Bapang, yang berdasarkan model pendekatan interpretasi lingkungan pengendapan (Nichols, 2009) merupakan fasies meandering river (Sungai berkelok-kelok). Formasi Bapang berumur Plistosen awal hingga plistosen tengah. 


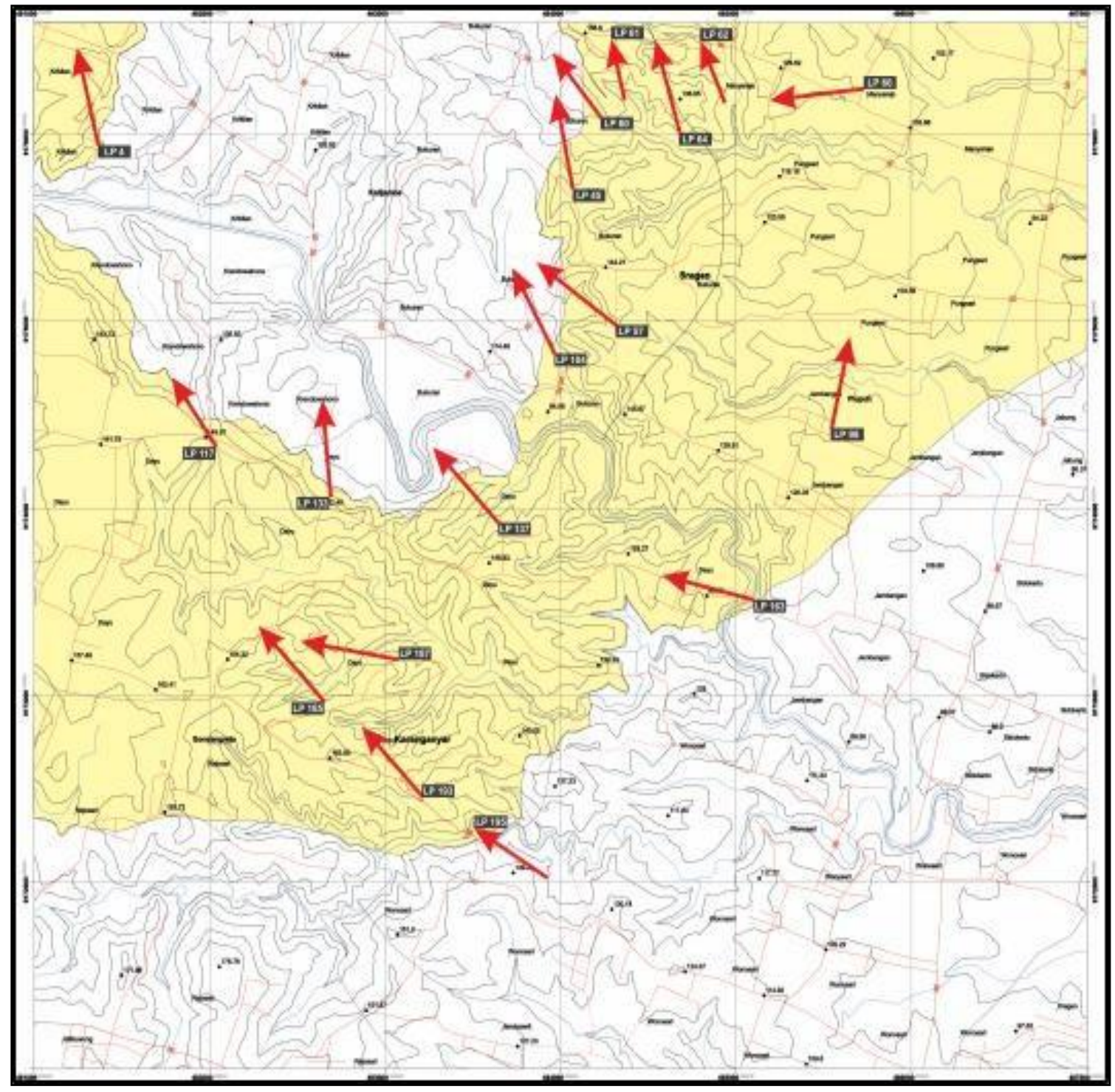

Gambar 9. Lokasi pengukuran dan persebaran arah arus purba Formasi Bapang. 

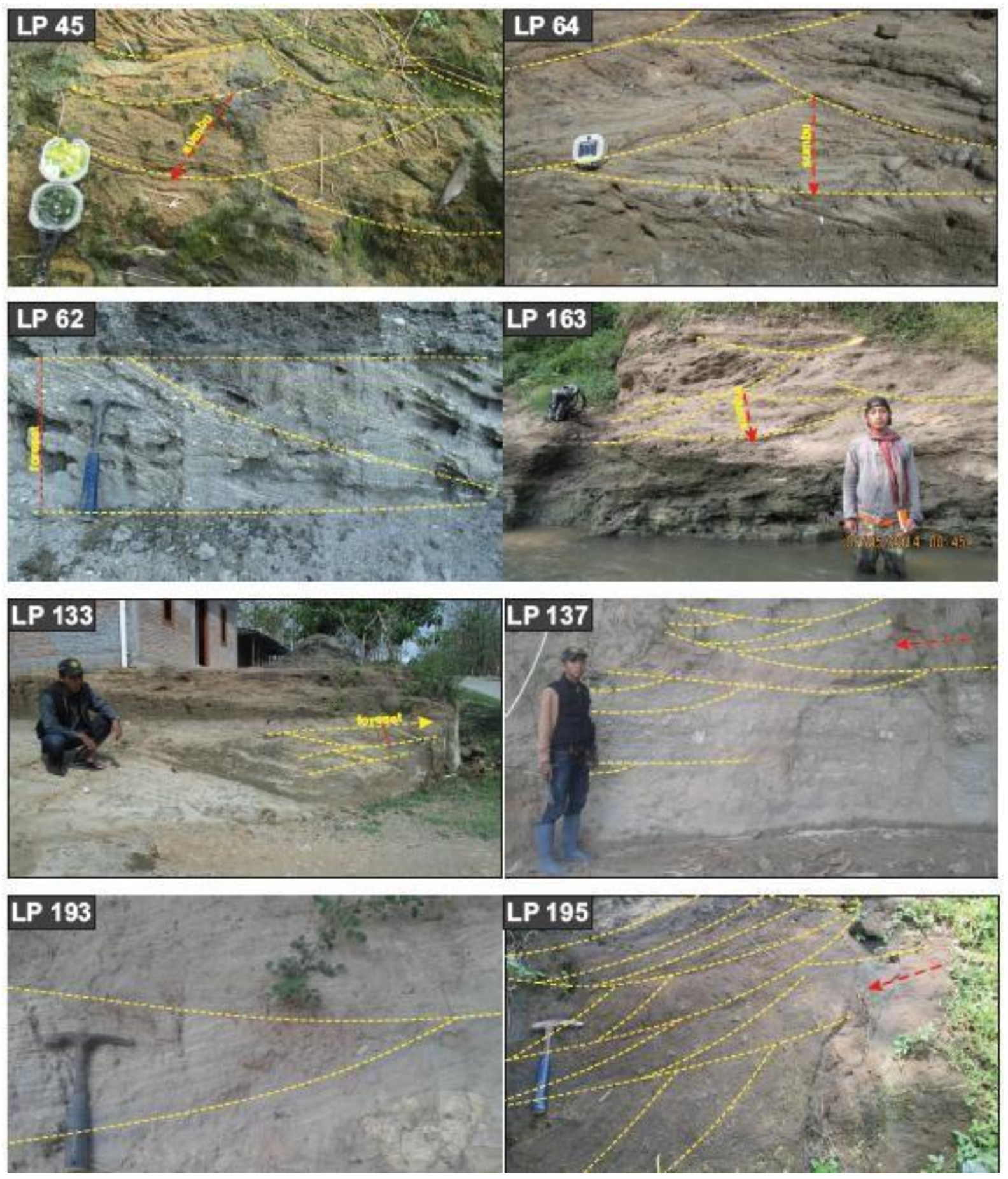

Foto 3. Kenampakan struktur trough cross-bedding pada 8 lokasi pengukuran. Garis kuning putus-putus menjelaskan bentuk struktur sedimen cross-bedding yang meneyerupai mangkuk dan tanda garis panah merah putus-putus menunjukan arah umum sumbu utama struktur sedimen cross-bedding. 
Tabel 2. Lingkungan pengendapan berdasarkan pola arus purba (Tucker, 2003)

\begin{tabular}{|c|c|c|}
\hline Environment & Directional structures & Typical dispersal patterns \\
\hline Aeolian & large-scale cross-bedding & $\begin{array}{l}\text { unimodal common, also } \\
\text { bimodal and polymodal; } \\
\text { depend on wind } \\
\text { directions/dune tvpe }\end{array}$ \\
\hline Fluvial & $\begin{array}{l}\text { cross-bedding, also } \\
\text { parting lineation, ripples, } \\
\text { cross-lamination, } \\
\text { channels }\end{array}$ & $\begin{array}{l}\text { unimodal down } \\
\text { palaeoslope, dispersion } \\
\text { reflects river sinuosity }\end{array}$ \\
\hline Deltaic & $\begin{array}{l}\text { cross-bedding, also } \\
\text { parting lineation, ripples, } \\
\text { channels }\end{array}$ & $\begin{array}{l}\text { unimodal directed } \\
\text { offshore, but bimodal or } \\
\text { polymodal if marine } \\
\text { processes important }\end{array}$ \\
\hline Marine shelf & $\begin{array}{l}\text { cross-bedding, also } \\
\text { ripples, fossil } \\
\text { orientations, } \\
\text { flutes/grooves on bases } \\
\text { of storm beds }\end{array}$ & $\begin{array}{l}\text { bimodal common } \\
\text { through tidal current } \\
\text { reversals but can be } \\
\text { normal or parallel to } \\
\text { shoreline; unimodal and } \\
\text { polymodal patterns }\end{array}$ \\
\hline Turbidite basin & $\begin{array}{l}\text { flutes, also grooves, } \\
\text { parting lineation, ripples }\end{array}$ & $\begin{array}{l}\text { unimodal common, } \\
\text { either downslope or } \\
\text { along basin axis if } \\
\text { turbidites, parallel to } \\
\text { slope if contourites }\end{array}$ \\
\hline
\end{tabular}

Berdasarkan hasil analisa stereografis, analisa diagram roset arah arus purba kompilasi, pola arah arus purba (Tucker, 2003), dan mengacu pada hasil analisa penampang stratigrafi terukur (Nichols, 2009), disimpulkan bahwa Formasi Bapang daerah Dayu terendapkan pada lingkungan Fluvial (Tucker, 2003). Dengan struktur sedimen penciri utama adalah cross-bedding yang menyebar (penciri meandering river), dan arah arus purba berpola unimodal mengarah kearah baratlaut.

\section{KESIMPULAN}

Dari semua uraian diatas kiranya dapat disimpulkan bahwa, Formasi Bapang merupakan formasi batuan yang didominasi oleh litologi batupasir tufan dengan struktur sedimen cross- bedding. Arah umum sumbu utama cross-bedding menuju kearah baratlaut membentuk pola unimodal dan menujukan bahwa arah arus purba formasi bapang berarah tenggara-baratlaut. Aspek fisik dan kimiawi Formasi Bapang menunjukan bahwa formasi ini terendapkan pada lingkungan sungai bekelok-kelok atau meandering river (Nichols, 2009), sedangkan hasil analisa lingkungan pengendapan berdasarkan pola arah arus purba menunjukan bahwa Formasi Bapang terendapkan di lingkungan fluvial (Tucker, 2003).

Hal tersebut saling mendukung bahwa lokasi persebaran Formasi Bapang pada daerah Dayu dahulu merupakan suatu lingkungan sungai yang berkelok-kelok dan berlangsung pada kala plistosen awal hingga plistosen tengah. Sungai ini mengalir dari hulu yang relatif berada di daerah tenggara, menuju ke hilir yang relatif berada di arah baratlaut. Aliran sungai tersebut diperkirakan sebagai media transportasi utama Material batupasir tufan penyusun Formasi Bapang. 


\section{DAFTAR PUSTAKA}

Danisworo, C., 1987, Lithostratigraphy and Magnetostratigraphy of the Quaternary Deposits in the Sangiran Area, Central Java, Indonesia. Vrije Universiteit Brussel. Doc. Thesis. Unpublished.

Duyfjes, J., 1936, Zur Geologie und Stratigraphie des Kendeng gebietes zwischem Trinil und Surabaya (Java). De Ing. Ned. Ind. hal. 4, 8, 136-148.

Indonesia-Japan Research Cooperation Program CTA 41., 1979, Prog. Report of the Indonesia-Japan Joint Research Project on Geol. of Human fossil Bearing Formations in Java (1). Bull. Geol. Res. And Dev.Center, No.1.

Nichols, G., 2009, Sedimentology and stratigraphy. $2^{\text {nd }}$ edition., John Wiley \& Sons, Ltd., Publication, United Kingdom, hal. 129-150.

Pringgoprawiro, H., 1983, Biostratigrafi dan Paleogeografi Cekungan Jawa Timur: Suatu Pendekatan Baru, Thesis Doktor, ITB, Bandung.

Sartono, S., 1961, Notes on a new find of a Pithecanthropus mandible. Publ. Tek., Dir. Geol., Seri Paleontologi, hal. 2, 1-51.

Sartono, S., 1970, On the stratigraphic position of Pithecanthropus mandible C. Proc. ITB, hal. 4, 91-92.

Sartono, S., 1975, Implication arising from Pithecanthropus VIII. In ; Tuttle, R.H. (Ed), Paleoanthropology: Morphology and Paleoeccology, 327-360, Mouton, Paris.

Sartono, S., 1978, The site of Homo erectus mandible F. Modern Quarter. Res. Southeast Asia, hal. 4, 19-24.

Satyana, A.H. and Arman, C., 2004, Deepwater Plays Of Java, Indonesia: Regional Evaluation On Opportunities And Risk, Proceeding Indonesia Petroleum Association, Twenty - Ninth Annual Convertion \& Exibition.

Tucker, M.E., 2003, Sedimentary Rocks in the Field. $3^{\text {rd }}$ edition., John Wiley \& Sons, Ltd., Publication, United Kingdom, hal.179-190.

Van Bemmelen, R. W., 1949, “The Geology of Indonesia”, vol IA, $2^{\text {nd }}$ ed, The Haque Martinus Nijhoff, Netherlands.

Van Koenigswald, G. H. R., 1940, Neue Pithecantropus-Funda 1936-1938. Ein beitharg zur Kennitis der Praehominiden. Wetensch, Meded. No. 28. Dienst. Mijnb.Ned. Indie.

Watanabe, N. and Kadar, D., 1985, Quaternary Geology of The Homonid fossil formation in Java. Directorate General of Geology and Mineral Research, Geological Research \& Development Centre. Special Publication. 